\title{
Distances walked in the six-minute walk test: suggestion of defining characteristic for the nursing diagnosis Ineffective Peripheral Tissue Perfusion ${ }^{1}$
}

\author{
Rita de Cassia Gengo e Silva² \\ Ludimila Brunorio ${ }^{3}$ \\ Cassiana Rosa Galvão Giribela ${ }^{4}$ \\ Luiz Aparecido Bortolotto ${ }^{5}$ \\ Nelson Wolosker ${ }^{5}$ \\ Fernanda Marciano Consolim-Colombo ${ }^{6}$
}

\begin{abstract}
Distances walked in walking tests are important functional markers, although they are not accepted as defining characteristics of Ineffective Peripheral Tissue Perfusion. The aims of this study were to verify the distances participants with and without this nursing diagnosis walked in the six-minute walk test and if these measures may be considered defining characteristics of this phenomenon. Participants with (group $A ; n=65$ ) and without (group $B ; n=17$ ) this nursing diagnosis were evaluated regarding physical examination, vascular function and functional capacity. Participants of group A seemed to have worse vascular function and functional capacity compared with those of group B. Pain-free travelled distance was predictive of the nursing diagnosis. These results are important for the refinement of this diagnosis. In conclusion, this study provides evidences that the distances walked in the six-minute walk test may be considered defining characteristics of Ineffective Peripheral Tissue Perfusion.
\end{abstract}

Descriptors: Nursing Diagnosis; Walking; Intermittent Claudication; Validation Studies.

\footnotetext{
1 Paper extracted from Doctoral Dissertation "Validação das características definidoras do diagnóstico de enfermagem: perfusão tissular periférica ineficaz em pacientes com doença arterial obstrutiva periférica sintomática" presented to Faculdade de Medicina, Universidade de São Paulo, Brazil.

2 PhD, Instituto do Coração, Faculdade de Medicina, Universidade de São Paulo, Brazil.

${ }^{3}$ Specialist, Instituto do Coração, Faculdade de Medicina, Universidade de São Paulo, Brazil.

${ }^{4}$ MSc, Hospital das Clínicas, Faculdade de Medicina, Universidade de São Paulo, Brazil.

${ }^{5}$ Free lecturer, Associate Professor, Faculdade de Medicina, Universidade de São Paulo, Brazil. Instituto do Coração, Faculdade de Medicina, Universidade de São Paulo, Brazil.

${ }^{6}$ Free lecturer, Associate Professor, Faculdade de Medicina, Universidade de São Paulo, Brazil. Hospital das Clínicas, Faculdade de Medicina, Universidade de São Paulo, Brazil.
}

Corresponding Author:

Rita de Cassia Gengo e Silva

Instituto do Coração. Coordenação de Enfermagem

Av. Dr. Enéas de Carvalho Aguiar, 44, $2^{\circ}$ andar, Bloco I

Bairro: Cerqueira César

CEP: 05403-000, São Paulo, SP, Brasil

E-mail: rita.gengo@incor.usp.br 


\title{
Distâncias percorridas no teste de caminhada de seis minutos: proposta de característica definidora para o diagnóstico de enfermagem Perfusão Tissular Periférica Ineficaz
}

Distâncias percorridas em testes de marcha são importantes marcadores funcionais, porém, não são aceitos como características definidoras de Perfusão Tissular Periférica Ineficaz. Os objetivos foram verificar as distâncias percorridas no teste de caminhada de seis minutos, por participantes com e sem esse diagnóstico de enfermagem, e se tais medidas podem ser consideradas características definidoras desse fenômeno. A amostra foi composta por sujeitos com (grupo $A, n=65$ ) e sem (grupo $B, n=17$ ) Perfusão Tissular Periférica Ineficaz, avaliados quanto ao exame físico, à função vascular periférica e à capacidade funcional. Os participantes do grupo A apresentaram pior função vascular e capacidade funcional do que os do grupo B. Verificou-se que a distância percorrida livre de dor foi preditiva para a ocorrência do diagnóstico de enfermagem. Os resultados deste estudo são importantes para o refinamento desse diagnóstico. Conclui-se que as distâncias percorridas no teste de caminhada de seis minutos podem ser características definidoras de Perfusão Tissular Periférica Ineficaz.

Descritores: Diagnóstico de Enfermagem; Caminhada; Claudicação Intermitente; Estudo de Validação.

\section{Distancias recorridas en la prueba de caminata de los seis minutos: propuesta de característica definitoria para el diagnóstico de enfermería Perfusión Tisular Periférica Inefectiva}

\begin{abstract}
Las distancias en pruebas de marcha son importantes marcadores funcionales, pero no son aceptados como características de definición de la Perfusión Tisular Periférica Inefectiva. Los objetivos fueron determinar las distancias recorridas en la prueba de caminata de los seis minutos por los participantes con e sin el diagnóstico de enfermería y si esas medidas se pueden considerar características de definición de este fenómeno. Los participantes con (grupo $A, n=65$ ) y $\sin$ (grupo $B, n=17$ ) el diagnóstico fueron evaluados mediante examen físico, función vascular periférica y capacidad funcional. Los participantes del grupo A ha presentado peor función vascular y desempeño en la prueba de marcha do que aquellos del grupo B. La distancia recorrida libre de dolor fue predictiva del diagnóstico de enfermería. Los resultados de este estudio pueden contribuir para el refinamiento de este diagnóstico. Las distancias recorridas en la prueba de marcha se pueden considerar características de definición de este diagnóstico.
\end{abstract}

Descriptores: Diagnóstico de Enfermería; Caminata; Claudicación Intermitente; Estudios de Validación.

\section{Introduction}

Nursing diagnoses are an important framework for nurses in many settings, such as clinical, teaching and research. Among the structural elements of nursing diagnoses, defining characteristics (DC) are cues or inferences that cluster as manifestations of these diagnoses ${ }^{(1)}$. DC are strongly linked to diagnostic accuracy, which is known to improve the quality of nursing care and patient safety ${ }^{(2)}$.
The latest version of the NANDA-International (NANDA-I) taxonomy contains 201 approved nursing diagnoses $^{(1)}$. Among these, our research team has studied Ineffective Peripheral Tissue Perfusion (IPTP), which is defined as a "decrease in blood circulation to the periphery that may compromise health"(1). In 2008, IPTP was accepted as a new diagnosis in the NANDA-I classification $^{(1)}$. It is interesting to highlight that our 
group was the first to use this label ${ }^{(3)}$. Considering the definition and the DC, IPTP is very similar to Altered Tissue Perfusion, which was accepted in the 80's and further renamed Ineffective Tissue Perfusion( ${ }^{(4)}$, before being replaced by IPTP.

Some validation studies have been conducted with these nursing diagnoses. First, in 1990, a content validation study of Altered Tissue Perfusion was accomplished(5). In this study, 'cyanosis when the lower extremity is pendent' and 'claudication' were identified as the most important DC. Some years later, this nursing diagnosis was clinically validated in patients with vasculopathy of the lower limbs(6). Although altered capillary refill time was the most prevalent defining characteristic, more than $70 \%$ of their sample showed claudication. In turn, IPTP was clinically validated in patients with hypertensive cardiomyopathy through methods that evaluate the vasomotor function. Authors validated four DC, among which claudication was associated with arterial stiffness ${ }^{(3)}$.

Claudication seems to be an important marker of IPTP and is well established in the literature as the main manifestation of the imbalance between oxigen supply and consumption in the skeletal muscles of the lower limbs. This symptom is manifested as the inability of the patient to continue walking for longer distances after a discomfort or pain, like a cramp, appears in a specific muscular group of the lower limbs, especially in the calves, while walking. Commonly, claudication is caused by narrowing of the arteries, leading to a loss of arterial blood pressure through the arterial system of the lower limbs(7). Several studies have related claudication to limitations of exercise perfomance and walking ability during daily life and the symptom appears to be associated with functional decline over the years $^{(8)}$ and worse quality of life ${ }^{(9)}$. In general, various methods can be used to evaluate patients' functional capacity $^{(10)}$. Among them, the six-minute walk test (6MWT) has shown reliability ${ }^{(11)}$ and is correlated with physical activity during daily life ${ }^{(10)}$.

Despite the clinical and epidemiological relevance of functional claudication distances, NANDA-I has not currently established the degree of functional limitation to affirm IPTP. In this context, the aims of this study were to verify the total and pain-free distances walked by patients with IPTP and to verify if distances travelled in the 6-MWT may be considered as DC of IPTP.

\section{Method}

\section{Subjects}

In this cross-sectional, descriptive and correlational study, 82 participants were recruited at a public outpatient service specialized in vasculopathies (participants with claudication) and in groups of seniors (participants without disease) and were divided into two groups: group A $(n=65)$ with IPTP and group $B(n=17)$ without IPTP. According to the definition of IPTP(1), and considering the interruption of blood flow due to narrowing arteries as the related factor of this nursing diagnosis ${ }^{(4)}$, all participants who referred claudication and had an ankle brachial index (ABI) below or equal to 0.90 were diagnosed with IPTP. On the other hand, participants without IPTP were those without risk factors for or detectable atherosclerotic disease. Thus, participants in group $B$ did not have claudication and their ABI should be between 0.90 and 1.30. Other inclusion criteria were being 40 years of age or older, independenlty of gender, being oriented in time, space and person, being able to walk without a walking aid and formally consenting to participate in the research by signing the informed consent term.

\section{Data collection}

All participants were evaluated regarding the presence or absence of selected defining characteristics (physical examination), the vascular function (pulse wave velocity and vascular reactivity) and the functional capacity (walking ability).

As many factors may interfere in the vascular function, evaluation participants were instructed to abstain from alcohol, caffeine, tobacco and exercise 48 hours prior to the study and to abstain from food 5 hours prior to the study. The principal investigator (RCGS) performed all procedures at the same time of day in a temperature-controlled room $\left(20^{\circ}-25^{\circ} \mathrm{C}\right)$. Blood pressure was measured through an oscillometric device (Omron HEM 741C, Omron Healthcare Inc., China) before ABI measurements, at the beggining and end of the vascular reactivity protocol.

\section{Physical examination}

Based on the NANDA-I classification, a literature review and previous studies regarding Altered Tissue 
Perfusion $^{(6)}$ and IPTP(3), ten DC were selected to put together participants' physical examination: diminished or absent pulses; femoral bruits; altered skin temperature, color, moisture, and hair; altered nails; altered capillary refill time; edema; and shiny skin. For all, operational definitions were established.

\section{Vascular function}

Vascular function was evaluated to verify if participants of both groups differed from a physiological perspective. In this perspective, alterations in distances walked may be attributed to arterial function impairment. Two procedures were conducted to evaluate vascular function: pulse wave velocity and vascular reactivity.

Pulse wave velocity

Pulse wave velocity (PWV) is inversely related to arterial wall distensibility and offers a non invasive method of assessing arterial stiffness(12). Elevated values of PWV are associated with atherosclerosis, hypertension and diabetes, indicating decreased arterial distensibility. To perform the PWV protocol, participants were placed in a supine position. Two transducers were fixed simultaneously at two different sites: 1) carotid and radial arteries (C-R) and 2) carotid and femoral arteries ( $\mathrm{C}-\mathrm{F}$ ). These transducers have membranes that are deformed by pulse wave shock. This deformation is transformed into an electrical signal that is transmitted to an electronic device - The Complior ${ }^{\circledR}$ (Colson, Garges les Gonesses, France) - for recording. The software calculated the time delay between the two corresponding foot waves, C-R and C-F, representing the pulse transit time $(T)$. The distance (D) the pulse wave travelled between the recording sites was determined at the end of the examination, based on superficial measurements of the direct distance between the two transducers. The PWV was calculated using the formula: PWV $=\mathrm{D} / \mathrm{T}$. Ten pressure waveforms were obtained per patient, and a mean PWV was calculated for both, $C-R$ and $C-F^{(12)}$.

Vascular reactivity

Participants lay supine with both arms out to their sides for at least 15 minutes before the initial examination and remained in this position throughout the study protocol. Heart rate was monitored via threelead ECG. All measurements were made following previously published guidelines ${ }^{(13)}$. Briefly, a 7 to 12 $\mathrm{MHz}$ high resolution linear array transducer (Sequoia Echocardiography System, version 6.0, Acuson,
Siemens, Ca, USA) was used to measure the left brachial artery diameter from 2-dimensional grayscale ultrassound imaging in B-mode at rest, during reactive hyperemia, at rest again and after a sublingual single dose $(0.45 \mathrm{mg})$ of nitroglycerin spray. Scans were performed at an insonation angle of 60 degrees. The images were recorded in VHS for future analysis with specific software.

-Reactive hyperemia: It is known that reactive hyperemia induces endothelium-dependent vasodilation through shear stress (FMD). An occlusion cuff was placed around the forearm, below the area where the brachial artery diameter was measured, proximal to the antecubital fossa. Baseline diameters were recorded for 1 minute prior to occlusion cuff inflation. The occlusion cuff was then inflated with $50 \mathrm{mmHg}$ above systolic blood pressure for 5 minutes. After release of the cuff occlusion, the brachial diameter was recorded for 90 seconds after cuff deflation.

-Nitroglycerin: It is known that nitroglycerin induces endothelium-independent vasodilation, since it is a "donor" of nitric oxide to vascular smooth muscle cells (NID). Baseline diameters were recorded for 1 minute prior to nitroglycerin administration. After 5 minutes, the brachial diameter was recorded for one minute. A physician assisted the protocol.

-Vessel diameter: Vessel diameter was analyzed off-line, using an automated edge-detection software package. The programme is triggered to the ECG signal and provides a diameter measurement for every selected $\mathrm{R}$ wave. We performed this analysis for six $\mathrm{R}$ waves in basal, during reactive hyperemia, basal again and after nitroglycerin administration. The final diameter for each phase was given as the median of those six diameters captured at the R waves. FMD and NID were expressed as the percentage changes in the brachial artery diameter during reactive hyperemia (\%FMD) and after nitroglycerin administration (\%NID), respectively.

\section{Functional capacity}

Functional capacity was evaluated through walking ability. For this purpose, participants performed a 6-MWT. Participants were instructed to walk up and down a 20-m corridor for 6 minutes after instructions to cover as much distance as possible, according to their tolerance, and to refer all symptoms during the walk. Total and pain-free distances were registered.

\section{Statistical analysis}

Data were analyzed through R 2.9 and SAS 9.1 
softwares. Inferential analysis was performed through Mann-Whitney, Fisher's exact test and chi-square. The significance level was $5 \%$.

To verify the extent to which distances walked in the 6-MWT were indicative of IPTP, variables were analyzed through a multiple binary logistic regression model. Two models were developed. Model 1 included all $D C$ related to pulse examination that showed statistical differences between groups A and B. These DC were grouped in a single variable named "Diminished or absent peripheral pulses and left femoral bruit". Model 2 included the other DC that showed statistical differences between both groups. These DC were grouped in a single variable named "DC of the second model". Also, functional variables (PWV, vascular reactivity and distances travelled in the 6-MWT) were selected through the forward stepwise model and included in Model 2. Variables were included in and excluded from Model 2 were perfomed through Escore and Wald tests. The level of significance used for inclusion and exclusion was $5 \%$. Sensibility and specificity were calculated for each model.

\section{Ethical aspects}

In compliance with Resolution 196/96, approval for the research project was obtained from the Ethics Committee of our Hospital (Protocol No. 006/05).

\section{Results}

\section{Subject characteristics}

Both groups, $A$ and $B$, were similar in relation to age (62.2 \pm 8.1 vs. $63.4 \pm 8.7, p>0.05)$, gender distribuition (male: $56.9 \%$ vs. $41.2 \%, p>0.05$ ), body mass index (26.6 \pm 4.1 vs. $26.8 \pm 4.4, p>0.05)$ and physical activity ( $24.6 \%$ vs. $17.6 \%, p>0.05)$. History of tobacco use was more common in group A ( $81.6 \%$ vs. $35.3 \%, p<0.001)$ and comorbidities (diabetes, arterial hypertension, coronary artery disease and stroke) only occurred in this group.

\section{Defining characteristics}

The distribution of DC is shown in Table 1.

Among the selected DC, all were more prevalent in group A, except for altered skin hair and temperature, which did not show statistical differences between groups, and shiny skin and edema, which were not observed in any participant.
Table 1 - Distribution of defining characteristis among participants in groups A (with IPTP) and B (without IPTP). Sao Paulo, Brazil, 2010

\begin{tabular}{|c|c|c|c|}
\hline Defining characteristics & $\begin{array}{l}\text { Group A } \\
(n=65)\end{array}$ & $\begin{array}{c}\text { Group B } \\
(n=17)\end{array}$ & $\mathbf{p}$ \\
\hline $\begin{array}{l}\text { Absent or weak right } \\
\text { femoral pulse }\end{array}$ & $29.2 \%(n=19)$ & $0.0 \%(n=0)$ & 0.009 \\
\hline $\begin{array}{l}\text { Absent or weak left } \\
\text { femoral pulse }\end{array}$ & $20.0 \%(n=13)$ & $0.0 \%(n=0)$ & 0.060 \\
\hline $\begin{array}{l}\text { Absent or weak right } \\
\text { popliteal pulse }\end{array}$ & $73.8 \%(n=48)$ & $0.0 \%(n=0)$ & $<0.001$ \\
\hline $\begin{array}{l}\text { Absent or weak left } \\
\text { popliteal pulse }\end{array}$ & $75.4 \%(n=49)$ & $0.0 \%(n=0)$ & $<0.001$ \\
\hline $\begin{array}{l}\text { Absent or weak right } \\
\text { dorsalis pedis pulse }\end{array}$ & $70.8 \%(n=46)$ & $5.9 \%(n=1)$ & $<0.001$ \\
\hline $\begin{array}{l}\text { Absent or weak left } \\
\text { dorsalis pedis pulse }\end{array}$ & $73.8 \%(n=48)$ & $5.9 \%(n=1)$ & $<0.001$ \\
\hline $\begin{array}{l}\text { Absent or weak right } \\
\text { posterior tibial pulse }\end{array}$ & $76.9 \%(n=50)$ & $5.9 \%(n=1)$ & $<0.001$ \\
\hline $\begin{array}{l}\text { Absent or weak left } \\
\text { posterior tibial pulse }\end{array}$ & $81.5 \%(n=53)$ & $0.0 \%(n=0)$ & $<0.001$ \\
\hline Right femoral bruit & $18.5 \%(n=12)$ & $0.0 \%(n=0)$ & 0.063 \\
\hline Left femoral bruit & $24.6 \%(n=16)$ & $0.0 \%(n=0)$ & 0.034 \\
\hline Altered skin hair & $26.2 \%(n=17)$ & $17.6 \%(n=3)$ & 0.542 \\
\hline Altered nails & $69.2 \%(n=45)$ & $11.8 \%(n=2)$ & $<0.001$ \\
\hline Altered capillary refill time & $33.8 \%(n=22)$ & $0.0 \%(n=0)$ & 0.004 \\
\hline Altered skin moisture & $30.8 \%(n=20)$ & $0.0 \%(n=0)$ & 0.009 \\
\hline Altered skin color & $23.1 \%(n=15)$ & $0.0 \%(n=0)$ & 0.033 \\
\hline Altered skin temperature & $16.9 \%(n=11)$ & $0.0 \%(n=0)$ & 0.109 \\
\hline
\end{tabular}

\section{Vascular function and functional capacity}

The mean values and standard deviation of vascular reactivity (DMF and NID), pulse wave velocity (PWV C-F and PWV C-R) and distances walked in the 6-MWT (total and pain free) are shown in Table 2.

Table 2 - Mean values and standard deviation of vascular reactivity (DMF and NID), pulse wave velocity (PWV $\mathrm{C}-\mathrm{F}$ and PWV C-R) and distances walked in the 6-MWT by participants in groups A (with IPTP) and B (without IPTP). Sao Paulo, Brazil, 2010

\begin{tabular}{lccc}
\hline \multicolumn{1}{c}{ Variable } & Group A $(\mathbf{n}=\mathbf{6 5})$ & Group $\mathbf{B}(\mathbf{n}=\mathbf{1 7})$ & $\mathbf{p}$ \\
\hline DMF & $2.7 \pm 4.2$ & $6.1 \pm 5.4$ & 0.0137 \\
NID & $14.3 \pm 8.4$ & $20.6 \pm 10.0$ & 0.0192 \\
PWV C-F & $12.2 \pm 4.0$ & $9.6 \pm 2.2$ & 0.0161 \\
PWV C-R & $8.6 \pm 1.9$ & $8.3 \pm 1.4$ & 0.6003 \\
Total distance & $265.1 \pm 77.4$ & $354.7 \pm 42.1$ & 0.0003 \\
Pain-free distance & $185.7 \pm 98.9$ & $354.7 \pm 42.1$ & 0.0014 \\
\hline
\end{tabular}

DMF and NID were lower in group $A$ when compared with group $B$, suggesting that participants with IPTP have a worse vascular function, including 
an impairment in the vascular smooth muscle. Moreover, PWV C-F was higher among participants in group $A$, which means that the distensibility of elastic arteries is smaller when compared with group $B$. In relation to functional capacity, participants with IPTP (group A) walked significantly shorter total and pain-free distances in the 6-MWT. It is interesting to note that functional distances (pain-free) and the ability to walk (total distance) among participants with IPTP correspond to $52.4 \%$ and $74.7 \%$ of the distances travelled by participants without IPTP, respectively. These data show that participants with IPTP have lower functional capacity and are less able to walk.
Defining characteristics, vascular function and functional capacity: ability to discriminate the nursing diagnosis

The ability of the variables in this study to distinguish IPTP was evaluated through models 1 (Table 3) and 2 (Table 4).

Table 3 - Odds ratio and confidence interval (CI) for the presence of IPTP, according to predictive variable of model 1. Sao Paulo, Brazil, 2010

\begin{tabular}{lcccc}
\hline \multicolumn{1}{c}{ Variable } & Estimation & $\begin{array}{c}\text { Standard } \\
\text { error }\end{array}$ & $\mathbf{p}$ & $\begin{array}{c}\text { Odds ratio } \\
\text { (CI) }\end{array}$ \\
\hline $\begin{array}{l}\text { Intercept } \\
\begin{array}{l}\text { Diminished or absent } \\
\text { peripheral pulses } \\
\text { and left femoral bruit }\end{array}\end{array}$ & -2.8 & 1.0 & 0.0071 & \\
\hline
\end{tabular}

Table 4 - Odds ratio and confidence interval (CI) for the presence of IPTP, according to predictive variables of model 2. Sao Paulo, Brazil, 2010

\begin{tabular}{|c|c|c|c|c|}
\hline Variable & Estimation & Standard error & $\mathbf{P}$ & Odds ratio $(\mathrm{Cl})$ \\
\hline Intercept & 14.854 & 5.883 & 0.012 & \\
\hline Defining characteristics of the second model ${ }^{*}$ & 3.367 & 1.164 & 0.004 & $29.004(2.964-283.786)$ \\
\hline Pain free travelled distance & -0.049 & 0.019 & 0.008 & $0.952(0.918-0.987)$ \\
\hline
\end{tabular}

*Altered skin moisture or altered capillary refill time or altered skin color or altered nails

These results show that participants with "diminished or absent peripheral pulses and left femoral bruit" are more likely to have IPTP when compared with those without the nursing diagnosis. For this model, the sensibility was $98.5 \%$ and the specificity $94.1 \%$. Moreover, the presence of "DC of the second model" increased the chance of IPTP by 29 times. In turn, model 2 shows that a one-meter increase in the painfree distance walked reduced the chance of IPTP by $5 \%$. For model 2, the area under the ROC curve was 0.976, suggesting high sensitivity and specificity.

\section{Discussion}

Clinical validation of nursing diagnoses remains a challenge for nurses, but this kind of study is important because it offers relevant contributions to clinical practice $^{(14)}$. Nurses are more likely to conduct content validation studies though. This method is easier and less expensive to accomplish than clinical validation. Nevertheless, the results obtained may be weak, since the content validation method primarily requires expert judgment. From this perspective, content validation only establishes that a group of experts has a common line of thought, but there is no guarantee that their judgment corresponds to the real world(15). Clinical validation studies may provide more robust results that, in fact, precisely depict what the nursing diagnosis proposes to depict. Regarding nursing diagnoses related to peripheral perfusion, clinical validation studies are $\operatorname{rare}^{(3,6)}$. At our best knowledge, none was conducted only with patients with arterial disease.

In the present study, it was shown that all DC were more prevalent among participants with IPTP regarding the interruption of blood flow to the lower limbs. Diminished or absent popliteal, dorsalis pedis and posterior tibial pulses were the most frequent alterations in the physical examination (Table 1 ). It suggests that this type of evaluation is relevant to detect IPTP. Indeed, one participant in group $B$ showed diminished dorsalis pedis and posterior tibial pulses. These findings were not considered evidences of IPTP though, because his/her limb hemodynamics was not compromised since he/she did not have claudication and the ABI was in the normal range. Through the multiple binary logistic regression model, we found that alterations in pulse examination are strongly predictive of IPTP. Several studies have shown that absent or weak pulses are the main clinical findings in patients with peripheral arterial obstructive disease $^{(16-17)}$.

The other DC were less prevalent $(<70 \%)$. If they 
had been analysed according to Fehring's method(18), most of them would not be considered as DC of IPTP, but we decided to conduct another type of analysis to determine if they would be predictive of IPTP. Thus, when these DC are analysed individually, they seem to be weak evidences of IPTP, although their prevalences are statiscally significant when comparing both groups, with and without IPTP. However, when these DC were grouped according to a statistic model, we found they are predictive of IPTP.

Moreover, our results showed that groups $A$ and $B$ differed in relation to vascular function and functional capacity. Participants with IPTP had worse vascular reactivity (DMF and NID were lower when compared with participants without IPTP), showed higher PWV C-F and were less able to walk. It means that participants with IPTP are different from participants without IPTP, not only regarding physical examination, but in a perspective that involves vascular functioning and functional capacity of the lower limbs.

This new viewpoint on nursing diagnoses should call nurses' attention. Previous studies demonstrated that endothelial dysfunction (evaluated by DMF) is of independent predictive value for cardiovascular events in clinical(19) and surgical(20) patients with peripheral arterial disease. Furthermore, it is known that nitric oxide is important to regulate microvascular blood flow of the skin and regions with arteriovenous anastomoses ${ }^{(21)}$. In the present study, participants with IPTP showed an impairment of the endothelial function (DMF) and the vascular smooth muscle (NID). These findings may suggest a link between IPTP and cardiovascular prognosis and that the altered skin characteristics observed in participants with IPTP are related with altered vascular function. In relation to PWV C-F, participants with IPTP experienced greater arterial stiffness. This finding is probably related to alterations in the structures of the arteries ${ }^{(12)}$, which may lead to an increase in vascular resistance and a decreased blood flow in the lower limbs ${ }^{(22)}$.

Regarding functional capacity, participants with IPTP are less able to walk when compared to participants without the nursing diagnosis. This finding has been associated with an impairment in daily ambulatory activity patterns ${ }^{(10)}$. Indeed, among functional variables (vascular reactivity, vascular stiffness and functional capacity), model 2 shows that pain-free distance walked is predictive of IPTP. According to model 2, a one-meter increase in the pain-free distance decreased the chance of IPTP by about $5 \%$. Clinical implications of this finding are numerous. Besides the effects of claudication on kinematics during walking(23) in patients with peripheral arterial disease, they are more likely to display a functional decline at 2-year follow-up( ${ }^{(8)}$ and have more chance of mortality ${ }^{(24)}$. In fact, when patients with intermittent claudication are evaluated through walk tests, it is observed that they walk shorter distances, but a simple intervention like a walking program may improve their functional capacity ${ }^{(25)}$.

\section{Conclusion}

In this study, pain-free distances were about 50\% lower among participants with IPTP when compared with age and gender-matched participants without the nursing diagnosis. Although our results showed that participants with IPTP are less able to walk (they walked shorter total distances compared with participants witout IPTP), only pain-free distances were predictive of IPTP. Despite the small sample, the present study provides strong evidence that the pain free travelled distances may be considered as DC of IPTP.

These findings may have several implications for nurses. The first is the evaluation of an aspect of this human response that is strongly linked with physical activity during daily life and, consequently, with the quality of life. During data collection, many participants with IPTP described that their physical limitation to walk was associated with low self-steem and social isolation. The second one is related to obtaining a variable that can be objectively measured. Finally, since distances travelled in the 6-MWT are objectively measured, they can be used to evaluate the results of nursing interventions.

\section{References}

1. NANDA Internacional. Diagnósticos de Enfermagem da NANDA: definições e classificação 2009-2011. Porto Alegre: Artmed; 2010.

2. Lunney $M$, Paradiso $C$. Accuracy in interpreting human responses. Nurs Manage. 1995;26(10):48H-8K.

3. Silva RCG, Cruz DALM, Bortolotto LA, Irigoyen MCC, Krieger EM, Palomo JSH, et al. Ineffective peripheral tissue perfusion: clinical validation in patients with hypertensive cardiomiopathy. Int J Nurs Terminol Classif. 2006;17(2):97-107.

4. North American Nursing Diagnosis Association (NANDA). Diagnósticos de enfermagem: definições e classificação 2007-2008. Porto Alegre: Artmed; 2008.

5. Tucker D. Altered peripheral tissue perfusion: use of defining characteristics in clinical practice. Nurs Diagn. 
1990;1(4):175-7.

6. Bersusa AAS, Cianciarullo TI. Validação do diagnóstico de enfermagem: alteração da perfusão tissular periférica em vasculopatas de membros inferiores. Nursing (São Paulo). 2001;4(43):29-34.

7. Wolosker N, Rosoky RA, Nakano L, Basyches M, Puech-Leão P. Predictive value of the ankle-brachial index in the evaluation of intermittent claudication. Rev Hosp Clin Fac Med Sao Paulo. 2000;55(2):61-4.

8. McDermott MM, Liu K, Greenland P, Guralnik JM, Criqui $\mathrm{MH}$, Chan $\mathrm{C}$, et al. Functional decline in peripheral arterial disease: associations with the ankle brachial index and leg symptoms. JAMA. 2004;292(4)453-61.

9. Koivunen K, Lukkarinen $\mathrm{H}$. Lower limb atherosclerotic disease causes various deteriorations of patients' healthrelated quality of life. J Vasc Nurs. 2006;24(4):102-15. 10. McDermott MM, Ades PA, Dyer A, Guralnik JM, Kibbe $M$, Criqui $M H$. Corridor-based functional performance measures correlate better with physical activity during daily life than treadmill measures in persons with peripheral arterial disease. J Vasc Surg. 2008;48:1231-7. 11. Cunha-Filho IT, Pereira DAG, Carvalho AMB, Campedeli L, Soares M, Freitas JS. Reliability of walking tests in claudicating patients: a pilot study. J Vasc Bras. 2008;7(2):106-11.

12. Laurent S, Cockcroft J, Van Bortel L, Boutouyrie P, Giannattasio C, Hayoz D, et al. Abridged version of the expert consensus document on arterial stiffness. Artery Res. 2007;1:2-12.

13. Corretti MC, Anderson TJ, Benjamin EJ, Celermajer D, Charbonneau F, Creager MA, et al. Guidelines for the ultrasound assessment of endothelial-dependent flowmediated vasodilation of the brachial artery: a report of the International Brachial Artery Reactivity Task Force. J Am Coll Cardiol. 2002;39(2):257-65.

14. Melo AS, Carvalho EC, Haas VJ. Defining characteristics, validated by specialists and manifested by patients: a study of the sexual dysfunction and ineffective sexuality pattern diagnoses. Rev. Latino-Am. Enfermagem. 2008;16(6):951-8.

15. Parker L, Lunney M. Moving beyond content validation of nursing diagnoses. Nurs Diagn. 1998;9(4):144-50.

16. Khan NA, Rahim SA, Anand SS, Simel DL, Panju A. Does the clinical examination predict lower extremity peripheral arterial disease? JAMA. 2006;295(5):536-46. 17. Criqui $\mathrm{MH}$, Fronek $\mathrm{A}$, Klauber MR, Barrett-Connor E, Gabriel S. The sensitivity, specificity, and predictive value of traditional clinical evaluation of peripheral arterial disease: results from noninvasive testing in a defined population. Circulation. 1985;71(3):510-5.

18. Fehring R. Methods to validate nursing diagnoses.
Heart Lung. 1987;16(6 Pt 1):625-9.

19. Brevetti G, Silvestro A, Schiano V, Chiariello M. Endothelial dysfunction and cardiovascular risk prediction in peripheral arterial disease: additive value of flow-mediated dilation to ankle-brachial pressure index. Circulation. 2003;108(17):2093-8.

20. Gokce N, Keaney Jr JF, Hunter LM, Watkins MT, Menzoian JO, Vita JA. Risk stratification for postoperative cardiovascular events via noninvasive assessment of endothelial function: a prospective study. Circulation. 2002;105(13):1567-72

21. Lenasi $H$, Strucl $M$. The effect of nitric oxide synthase and cyclooxygenase inhibition on cutaneous microvascular reactivity. Eur J Appl Physiol. 2008;103(6):719-26.

22. Suzuki E, Kashiwagi A, Nishio Y, Egawa K, Shimizu S, Maegawa $\mathrm{H}$, et al. Increased arterial wall stiffness limits flow volume in the lower extremities in type 2 diabetic patients. Diabetes Care. 2001;24(12):2107-14.

23. Celis R, Pipinos II, Scott-Pandorf MM, Myers SA, Stergiou N, Johanning JM. Peripheral arterial disease affects kinematics during walking. J Vasc Surg. 2009;49(1):127-32. 24. McDermott MM, Tian L, Liu S, Guralnik JM, Ferrucci L, Tan J, et al. Prognostic value of functional performance for mortality in patients with peripheral artery disease. J Am Coll Cardiol. 2008;51(15):1482-9.

25. Wolosker N, Nakano L, Rosoky RA, Puech-Leão P. Evaluation of walking capacity over time in 500 patients with intermittent claudication who underwent clinical treatment. Arch Intern Med. 2003;163(19):2296-300.
Received: Jan. $16^{\text {th }} 2011$ Accepted: Sep. $20^{\text {th }} 2011$ 